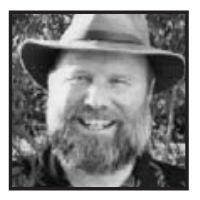

\title{
Adult Literacy ... and the Children Shall Lead
}

\author{
Joe Norris, Brock University
}

\section{ABSTRACT}

The author, a successful academic, admits that reading for him, as an extrovert, has been primarily considered a painful experience and throughout his schooling, he often viewed it as punishment. Through the needs of his nephew, the author and his brother, another non-reader, embark on a series of reading adventures that bring reading for pleasure into their lives and model it for family and friends. The article provides a justification for personal narrative as form of research and concludes with some insights on informal literacy advocacy.

\footnotetext{
Om Barone (1990) claims that story telling can be a research act that invites the reader to conspire or breathe (spire) with (con) with the author. When a reader resonates with a part of the story, the reader has a greater likelihood of bringing that part of the story to his or her living situation. It is the reader, not the research, that determines the generalizability of the research, as the reader finds what is applicable to a given situation and acts accordingly. Using the adage, "show; don't tell," themes and abstract concepts are imbedded within the story, rather than always being made explicit.
}

Short stories or vignettes can play a role in "research in practice." As we examine our practice (our autobiographies), we can find events that have moved us and may have the potential to move others. It is these stories that we are called to tell with the hope that others can use them in their own lives (Kopp, 1972). Storytelling can be both a literacy act and a research methodology (Reason \& Hawkins, 1988). 
The following is a literacy story that I have related verbally a number of times and now put to ink as an example of storytelling as a reflective research genre.

It was mid-evening when I received a call from my brother, Vincent, (permission given to use actual names) on the east coast of Canada. It had been months since we had talked and one of the few times that he had called me in Edmonton. While we were close, we had more of an in-person relationship. Phone calls were a rarity. This time he was on a mission. His son, Eric, was having reading difficulties at school and he called me, his older brother, an "education" professor, for help. Immediately, I confided that literacy was not a specialty of mine and while I felt that I had little specific expertise to offer, I would be happy to discuss the general situation with him.

My nephew's teacher had told my brother that his son was reading below grade level and with practice, he could improve. The difficulty was that his son did not want to read. But before discussing my nephew, my brother and I talked about our own educational experiences, discussing what we considered the problems we had with our schooling and how some of our experiences may shed some light on his son's situation. I related my own difficulties in grade two, long before my brother was born. I was given a book to read over the summer for "practice" but I considered it more of a punishment and did the task reluctantly. My brother related similar stories. I informed him that according to the Myers-Briggs Type Indicator (Myers \& McCaulley,1985) I was an extrovert and learned best with my mouth open. For me, reading was a solitary activity and therefore painful. My brother shared similar feelings about himself and his son. Being actively engaged with people was our preference and private reading was an intrusion on the way in which we saw ourselves in the world.

During this conversation we began to brainstorm approaches to take with his son and talked about how modeling was important. In my own home my wife and I purchased children's books for our daughters to read and to be read to. We had a supply of magazines along with the daily newspaper that were visible. They saw my wife and I reading at home. Both of my daughters are avid readers, and although I would hesitate to claim a strong cause-and-effect relationship between their reading and my modeling, I am certain that modeling was one of many factors.

I asked if he thought modeling might be useful. Vincent claimed that it could not hurt and was willing to give it a try. I asked if he had magazines around the home. He did not. Knowing that his son was into hockey, I asked if he thought that the 
purchasing of some hockey magazines might be a good idea. He was uncertain. Continuing to brainstorm for possibilities, I asked him if he had heard of the "Harry Potter" (Rowling, 1997) novels. Not only had he, but his daughter had also read them from cover to cover. "Good," I said, "Start reading Harry Potter." I also told him that I would put my proverbial "money where my mouth was" and would start reading Harry Potter along with him.

Being an academic one could surmise that I was/am an avid reader. However, I must confess that I am not. I read professionally and that is the extent of it. As mentioned earlier, my pleasure is found in being with people and reading for pleasure; being solitary, is not an option. I need to balance my solitary work-related reading activities with my need to be with others. But I had made a promise with the hope that my behavior and that of my brother might play a small part in my nephew's education. My brother and I would model reading "as an enjoyable way to entertain one's self and to understand the world" (Mikulecky, 1996, p. 57).

Over the next few months my brother and I called each other many times discussing Harry's exploits. He and I were hooked by the adventures at Hogwarts and would phone each other to discuss the characters, plot and issues that arose. Unintentionally, we had created our own literature circle (Daniels, 2002). These pieces of fiction created a new bond between my brother and I, and we were eager to share our thoughts with one another. Although the books were a pleasure to read, I also anticipated my brother's calls as he did mine. As extroverts, there was a need for a reading companion to discuss our thoughts (King, 2001). We found this in each other. Besides being an end in itself, reading had also become a means to another end, kinship.

Since then we finished the "Sword of Truth" series by Terry Goodkind (1994) and, on more than one occasion, to his delight, my brother was often ahead of me. I had stalled when I took a new administrative position and while my attention was directed elsewhere, Vincent continued to read.

Since that first phone call, the atmosphere in my brother's home has changed drastically. Vincent's wife, Becky, with a smile of amusement, told me that she has to ask him on a number of occasions to turn off the bedroom reading lights after midnight. She is proud of but sometimes strained with his new-found joy. He was disappointed when he received a gift certificate for a book for his birthday. Not because it was for a book, but because, due to his work schedule, he could not start reading immediately. Vincent would read on the bus going to and from work and at one time 
his family begged him—no, demanded — that he stop reading for a while. His household now views him as an avid reader, as does he.

Little did we know that his telephone request would bring us both to this adventure. Up until that moment neither of us would have defined ourselves, even remotely, as readers for pleasure. His son's need and J. K Rowling's delightful works brought us into a new and enriching world. As extroverts we found our ways into one of the many faces of literacy and began to look forward to some time alone with a new set of characters, albeit fictional.

Inadvertently, we stumbled onto a few insights that reinforce studies and activities of those working in literacy programs. 1) For some, reading may need to be tied to social activities that supplement and complement the loneliness of the solitary reader. My brother and I knew that we had someone to talk to about our reading (Powell-Brown, 2006). Encouraging someone to read aloud to another may be a way to address his/her social needs and find the pleasure in this type of reading. 2) Searching for materials that engage an individual is not and easy task and can take time. While I sporadically had read science fiction and my brother read nothing, the works of J. K Rowling engaged us, beckoning us to a new world. My sisters, $\mathrm{Cec}$ and Therese, and I found that we were both interested in soulful living and are beginning to share our interests with these types of books. Studies show that "students who believed that their school work was interesting and important were more cognitively engaged in trying to learn and understand it ... (and) ... social interaction is motivational" (Turner, 1995, p.418). My sisters and I found a shared interest, so the ripple continues with other members of this extended family. 3) Informal reading initiatives can be productive if we can find ways to encourage and support them. My brother's and my re-initiation to reading was as grassroots as it can get." ... helping parents use the informal events of everyday life as the primary way to promote children's literacy often works best and seems less like an assignment from school" (Wasik, 2004, p. 336).

In conclusion, I am surprised at how my nephew's need catapulted my brother's and my reading. Did my nephew read Harry Potter? Yes! Has his reading improved? Yes. Was it because of his father's reading? Maybe. Answers to this question require a different type of research. But what I have come to believe from this experience is that adult and children's literacy are interconnected. My nephew's need led his father, my brother, and I into a new and exciting world. "Literacy development is not limited to children. It occurs across the life span, and, for adults, it can occur in the informal settings of home and community as well as in more formal settings" (Wasik, 2004, p. 5). While we often believe that adults can model good practices for children, sometimes it is their needs that spur us on. 


\section{References}

Barone, T.E. (1990). Using the narrative text as an occasion for conspiracy. In E.W. Eisner \& A. Peshkin (Eds.), Qualitative Inquiry in Education (305-326). New York: Teachers College Press.

Daniels, H. (2002). Literature circles: Voice and choice in book clubs and reading groups. Markham: Pembroke Publishers Limited.

Goodkind, T. (1994). Wizard's first rule. New York: A Tom Doherty Associates Book.

King, C. (2001). "I like group reading because we can share ideas":The role of talk within the literature circle. Reading, 35(1), 32-36.

Kopp, S. (1972). If you meet the Buddha on the road, kill him. New York: Bantam.

Mikulecky, L. (1996). Family literacy: Parent and child interactions. In B. L. Ann \& J. E. Lord (Eds.), Family literacy: Directions in research \& implications for practice.
Myers, I. B., \& McCaulley, M. (1985). Manual: A guide to the development and use of the Myers-Briggs type indicator. Palo Alto, CA: Consulting Psychologists Press.

Powell-Brown, A. (2006). Why can't I just see the movie?: Fostering motivation in children who struggle with reading. Intervention in School and Clinic, 42(2), 84-90.

Reason, P., \& Hawkins, P. (1988). Storytelling as inquiry. In P. Reason (Ed.), Human Inquiry in Action (79-101). Newbury Park, CA: Sage Publications Inc.

Rowling, J. K. (1997). Harry Potter and the philosopher's stone. Vancouver: Raincoast Books.

Turner, J. C. (1995). The influence of classroom contexts on young children's motivation for literacy. Reading Research Quarterly, 30(3), 410-441.

Wasik, B. H. (2004). Handbook of family literacy. New York: Routledge.

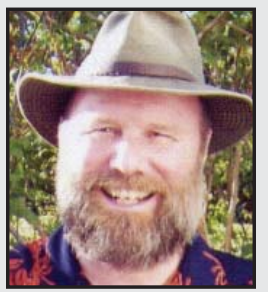

Joe Norris has worked in faculties of education for twenty years and now finds himself in a faculty of humanities at Brock University. He teaches courses in Drama in Education and Applied Theatre in the Department of Dramatic Arts in the Marilyn I. Walker School of Fine and Performing Arts. His recent book, "Playbuilding as Qualitative Research: A Participatory Arts-based Approach," is based upon his work with Mirror Theatre primarily while he was at the University of Alberta. 